\title{
Representation of Corporate Social Responsibility in Croatian Export Companies
}

\author{
Andrija Baric, Ph.D. \\ KONČAR - Power Plant and Electric Traction Engineering Inc., Croatia \\ Mislav Ante Omazič \\ University of Zagreb, Faculty of Economics and Business, Croatia
}

\begin{abstract}
Continuous globalization, rapid development of information-communication technologies, and the presence of new burning challenges for the global community have contributed to the perception of corporate social responsibility as a strategic tool that allows for successful differentiation and sustainable competitive advantage. The goal of this paper is to offer a short overview of the role of a strategic approach to corporate social responsibility, as well as emphasize the importance of such an approach in creating competitive advantage for a company, but also of sustainability of society as a whole. The paper is based on a primary research questionnaire conducted on middle-sized and large Croatian export companies, as well as a systematic analysis of previously published relevant international scientific papers in the area of corporate social responsibility.
\end{abstract}

Keywords: corporate social responsibility, strategy, stakeholders, differentation, Croatian export companies

JEL classification: $032,033, \mathrm{G} 34$

\section{Introduction}

The concept of corporate social responsibility presents an increasingly important topic which continuously affects the global economic network, as well as society as a whole. It is a concept that underwent many transformations throughout its history, and is now a key part of business strategy and the business model in modern corporations. It is evident that the importance of the concept will continue to grow rapidly in times of great global economic, societal and cultural changes (Taneja et al., 2011). Unlike many other similar concepts dealing with the relationship between company and community, corporate social responsibility is the most accepted concept because it includes responsibility, responsiveness, action and visible results (Carroll, 2015).

This paper demonstrates that adequate managerial governance improves the reputation of a company, thus generating long-term benefits and sustainability of business operations within a community. The most prominent idea behind this paper is the fact that in the couple of decades of its existence, the concept of corporate social responsibility has gone from a phase of "unnecessary dependence" to being a critical business model, and today demands a strategic approach by the management for the company to successfully differentiate itself from its competitors in the global economic network. Differentiation based on corporate social responsibility, whether a company differentiates itself from its competition in the context of an organizational unit or through certain products and services, will have a positive effect on the reputation of a company with its internal and external stakeholders. 
Many profit and non-profit organizations try to achieve a positive effect on internal and external stakeholders, as well as the general reputation of a company, by properly conducting and communicating socially responsible activities (Tata et al., 2015). Differentiation based on socially responsible activities generates the greatest benefits in time of great economic crises, during which internal and external stakeholders' trust in profit companies is diminished because at that time adequate conduct and communication of activities presents a key dimension which influences the readiness of consumers to pay a higher price for a product or service (Lins et al., 2017). A strategic approach to the concept of corporate social responsibility assumes that organizational culture, business and governing processes, as well as company strategy as the key document that generates all changes, adapt to the concept of corporate social responsibility and interests of key stakeholders (Carroll, 2015).

\section{Literature review}

Croatian companies and corporate social responsibility in practice As stakeholders throughout the global community become more aware of the existence of a growing number of societal, economic, ecological, cultural, and health challenges that can affect the way of life we know today, differentiation of companies based on corporate social responsibility presents an increasingly frequent strategic model of company differentiation in the global economic network (Boehe et al., 2010). For small and transition countries of Central and Eastern Europe, The Republic of Croatia included, internationalization of business presents a crucial condition that allows for continuity of investment in the development of local companies, which directly results in economic growth and a higher standard of living (Manolova et al., 2010). As a small and open economy, The Republic of Croatia cannot base its economic growth on local, but on international demand, or rather export activities focused on different markets throughout the world (Bogdan et al., 2015).

In order to achieve competitive advantage in the export market by differentiation of socially responsible activities, it is necessary to identify the interests of key internal and external stakeholder groups, as well as recognize the most efficient socially responsible activities and communication models, which can be used to present results of socially responsible activities to stakeholders (Scherer at al., 2008). Tai et al. (2014) emphasize that management of modern global corporations cannot focus exclusively on making profit, but rather work on setting and maintaining the foundations for sustainable community development

\section{Impact of business strategy on the concept of corporate social responsibility}

Even though the concept of corporate social responsibility can differ from society to society, today it has reached global maturity, and continues to spread daily within international scientific and business circles, yet the key determinants of the concept are still based on achieving financial returns from its activities (Carroll, 2015). In order for the management to create economic value for the organization and thus successfully differentiate itself from the competition by conducting and communicating socially responsible activities, activities and communication processes towards stakeholders must be integrated into the key strategy determinants, and consequently into the primary as well as secondary business processes (Kanji et al., 2010). 
Strategic implementation of corporate social responsibility directly enables the creation of a market position which local and international competitors will unlikely attain, because they would have to successfully imitate the entire set and not just a single socially responsible activity (Galbreath, 2009). Creating a market position, that enables sustainability of long-term competitive advantage, requires alignment with key stakeholder interests which further increases complexity of the strategic approach to corporate social responsibility, and prevents efficient imitation by competitors. With this in mind, corporate social responsibility acts as opportunity or threat to companies, and today serves more than just a "trinket" to business strategy itself (Lamberti et al., 2009). Key condition for successful implementation of corporate social responsibility into the strategy is the existence of the strategy of corporate social responsibility, as well as avoidance of unconnected individual corporate social responsibility initiatives which can do the organization more harm than good (Googins et al., 2006).

No less important, in order to allow differentiation from competitor companies, the entire organization and not just top management need to show intense dedication (Bluementhal et al., 2003). Tsoutsoura (2004) points out that it is of great importance that guidelines for socially responsible business present an indispensable part of organizational values, and that the management and the employees remain true to those guidelines. Only in such situations is it possible for a strategically coordinated transformation of organization culture from economic to value-based foundations (Maon et al., 2010).

Based on the aforementioned, it can be concluded that unplanned conducting and/or communicating of socially responsible activities can have a very negative effect on the business operations of a company in the short term, as well as prevent generation of returns on investment because of unsuccessful differentiation (Tang et al., 2012). Seeing as it takes time and other resources to strategically conduct and communicate socially responsible activities (Omazić, 2006), it is very important that through the strategy of corporate social responsibility management connects all activities with the goal of optimizing resources and creating higher returns on investments (Marcus et al., 2006). That said, Tang et al. (2012) point out that it is cost effective for the management to initially specialize in conducting activities which require similar knowledge, skills and resources, because simultaneous investment in a completely different spectrum of activities may endanger current business operations.

\section{Methodology}

Research has been carried out on a sample of middle-sized and large Croatian export companies. Croatian companies are those that in 2015, according to the Croatian Exporters Association, generated profits from export activities of goods and services amounting to at least $25 \%$ of their total profits. Export activities are defined as exports of goods and services by middle-sized and large export companies to international markets. International markets include all markets throughout the world, the European Union market included. Large and middle-sized companies are specified using the criteria regulated by the Law for Stimulation of Small Economic Subjects (NN 29/02, 63/07, 53/12,56/13, 121/16).

In order to form the construct of the prevalence of corporate social responsibility within the strategy of a company, definitions of the concept and company strategy have been presented. Corporate social responsibility is defined as the will of the management of an organization to include the effect of conducting business on society and the environment in the decision making process, as well as take 
responsibility regarding consequences arising from strategic and operating decisions. Primary dimensions of corporate social responsibility are defined as: organizational governance, human rights protection, regard for workers' rights, responsibility in business processes, interest for the problems of consumers, and the development of society (ISO 26000, 2010).

Company strategy presents a comprehensive framework containing guidelines for conducting business processes and accomplishing the mission of a company, while simultaneously efficiently allocating resources which allows it to produce and place products and services in accordance with market demands, in order to create and retain competitive advantage. It encompasses the mission, analysis of internal and external influences, market analysis, consumer analysis, allocation of key company resources, and competitive advantage (Galbreath, 2009; Tipurić, 2014).

By using the aforementioned definitions, a construct for measuring the representation of corporate social responsibility within the strategy of a company has been formed. The representation of corporate social responsibility within the strategy of a company is measured using the Likert scale $(1$ - Strongly Disagree, 5 - Strongly Agree).

\section{Table 1}

Construct for Measuring Corporate Social Responsibility Representation within the Strategy of a Company

\begin{tabular}{|c|c|c|}
\hline Code & Lot & Modalities \\
\hline DO_STRAT_1 & $\begin{array}{l}\text { Corporate social responsibility is } \\
\text { incorporated within company strategy as } \\
\text { one of the key strategy elements }\end{array}$ & $\begin{array}{l}\text { Likert scale }(1 \quad-\quad \text { Strongly } \\
\text { Disagree, } 5 \text { - Strongly Agree) }\end{array}$ \\
\hline DO_STRAT_2 & $\begin{array}{l}\text { Corporate social responsibility is } \\
\text { represented in the company mission which } \\
\text { is the key element of company strategy }\end{array}$ & $\begin{array}{l}\text { Likert scale }(1-\text { Strongly } \\
\text { Disagree, } 5 \text {-Strongly Agree) }\end{array}$ \\
\hline DO_STRAT_3 & $\begin{array}{l}\text { Corporate social responsibility is } \\
\text { represented within the analysis of internal } \\
\text { and external influences which is the key } \\
\text { element of company strategy }\end{array}$ & $\begin{array}{l}\text { Likert scale (1 - Strongly } \\
\text { Disagree, } 5 \text {-Strongly Agree) }\end{array}$ \\
\hline DO_STRAT_4 & $\begin{array}{l}\text { Corporate social responsibility is } \\
\text { represented within the market analysis } \\
\text { which is the key element of company } \\
\text { strategy }\end{array}$ & $\begin{array}{l}\text { Likert scale }(1-\text { Strongly } \\
\text { Disagree, } 5 \text {-Strongly Agree) }\end{array}$ \\
\hline DO_STRAT_5 & $\begin{array}{l}\text { Corporate social responsibility is } \\
\text { represented within the consumer analysis, } \\
\text { as primary stakeholders, which is the key } \\
\text { element of company strategy }\end{array}$ & $\begin{array}{l}\text { Likert scale }(1-\text { Strongly } \\
\text { Disagree, } 5 \text {-Strongly Agree) }\end{array}$ \\
\hline DO_STRAT_6 & $\begin{array}{l}\text { Corporate social responsibility is } \\
\text { represented during the allocation of key } \\
\text { company resources necessary for } \\
\text { conducting socially responsible activities }\end{array}$ & $\begin{array}{l}\text { Likert scale }(1-\text { Strongly } \\
\text { Disagree, } 5 \text {-Strongly Agree) }\end{array}$ \\
\hline DO_STRAT_7 & $\begin{array}{l}\text { Corporate social responsibility is planned } \\
\text { as an activity which contributes to } \\
\text { achieving competitive advantage }\end{array}$ & $\begin{array}{l}\text { Likert scale (1 - Strongly } \\
\text { Disagree, } 5 \text {-Strongly Agree) }\end{array}$ \\
\hline
\end{tabular}




\section{Results}

Table 2

Descriptive Statistics of the Representation of Corporate Social Responsibility Construct within the Strategy of a Company

\begin{tabular}{lccccc}
\hline & N & Min & Max & Average & St. Dev. \\
\hline DO_STRAT_1 & 78 & 1 & 5 & 4,23 & 0,805 \\
DO_STRAT_2 & 78 & 2 & 5 & 4,19 & 0,722 \\
DO_STRAT_3 & 78 & 1 & 5 & 3,82 & 0,936 \\
DO_STRAT_4 & 78 & 1 & 5 & 3,69 & 0,944 \\
DO_STRAT_5 & 78 & 2 & 5 & 3,85 & 0,823 \\
DO_STRAT_6 & 78 & 1 & 5 & 3,71 & 0,941 \\
DO_STRAT_7 & 78 & 1 & 5 & 3,95 & 0,952 \\
\hline
\end{tabular}

Source: Authors' work

Table 2 shows descriptive statistics of representation of the corporate social responsibility construct within the strategy of a company, consisting of seven lots: DO_STRAT_1, DO_STRAT_2, DO_STRAT_3, DO_STRAT_4, DO_STRAT_5, DO_STRAT_6 i DO_STRAT_7. Lots DO_STRAT_1 (Corporate social responsibility incorporated within company strategy as one of key strategy elements) $(4,23)$ and DO_STRAT_2 (Corporate social responsibility represented in company mission which is the key element of company strategy) $(4,19)$ have the highest average value. Lot DO_STRAT_4 (Corporate social responsibility represented within market analysis which is the key element of company strategy) $(3,69)$ has the lowest average value.

Figure 1

Average Values of Representation of the Corporate Social Responsibility Construct within Company Strategy

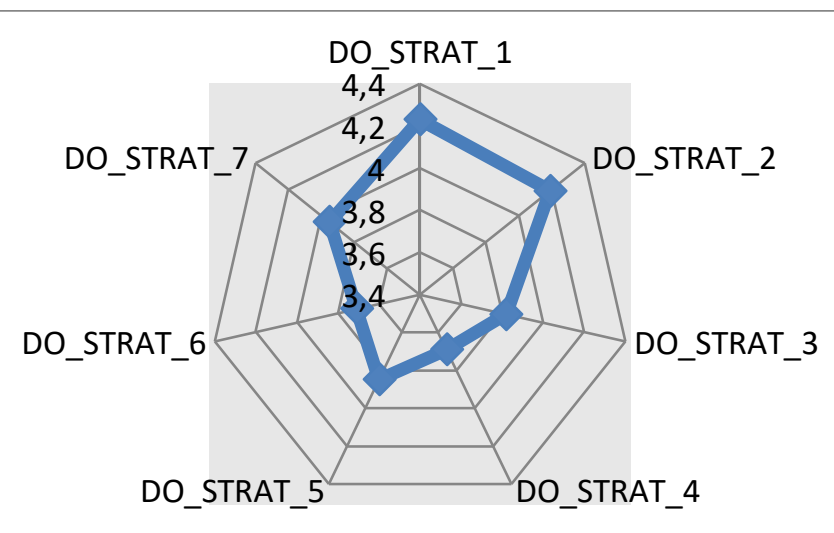

Source: Authors' illustration

Figure 1 shows average values of the representation of the corporate social responsibility construct within company strategy. It can be concluded that average values for all seven lots are very high, and range from 3,69 to 4,23. 


\section{Table 3}

Structure of Examinee Answers of Representation of the Corporate Social Responsibility Construct within Company Strategy

\begin{tabular}{lcccccc}
\hline & $\begin{array}{c}\text { 1 - Strongly } \\
\text { Disagree }\end{array}$ & $\mathbf{2}$ & $\mathbf{3}$ & $\mathbf{4}$ & $\begin{array}{c}\text { 5 - Strongly } \\
\text { Agree }\end{array}$ & Total \\
\hline DO_STRAT_1 & $1 \%$ & $3 \%$ & $8 \%$ & $49 \%$ & $40 \%$ & $100 \%$ \\
\hline DO_STRAT_2 & & $3 \%$ & $10 \%$ & $53 \%$ & $35 \%$ & $100 \%$ \\
\hline DO_STRAT_3 & $1 \%$ & $8 \%$ & $23 \%$ & $44 \%$ & $24 \%$ & $100 \%$ \\
\hline DO_STRAT_4 & $1 \%$ & $10 \%$ & $26 \%$ & $44 \%$ & $19 \%$ & $100 \%$ \\
\hline DO_STRAT_5 & & $8 \%$ & $19 \%$ & $54 \%$ & $19 \%$ & $100 \%$ \\
\hline DO_STRAT_6 & $1 \%$ & $10 \%$ & $24 \%$ & $45 \%$ & $19 \%$ & $100 \%$ \\
\hline DO_STRAT_7 & $3 \%$ & $5 \%$ & $17 \%$ & $46 \%$ & $29 \%$ & $100 \%$ \\
\hline
\end{tabular}

Source: Authors' work

Table 3 shows the structure of examinee answers of representation of the corporate social responsibility construct within company strategy. Most examinees strongly agree with the following statements regarding representation of corporate social responsibility within company strategy: DO_STRAT_1 (Corporate social responsibility incorporated within company strategy as one of key strategy elements) (40\%) and DO_STRAT_2 (Corporate social responsibility represented in the company mission which is the key element of company strategy) (35\%). Also, almost $50 \%$ of examinees agree with all the aforementioned statements, i.e. they gave it a four (DO_STRAT_1 (49\%), DO_STRAT_2 (53\%), DO_STRAT_3 (44\%), DO_STRAT_4 (44\%), DO_STRAT_5 (54\%), DO_STRAT_6 (45\%) i DO_STRAT_7 (46\%)).

Figure 2

Graphic Display of the Structure of Examinee Answers for the Representation of the Corporate Social Responsibility Construct within Company Strategy

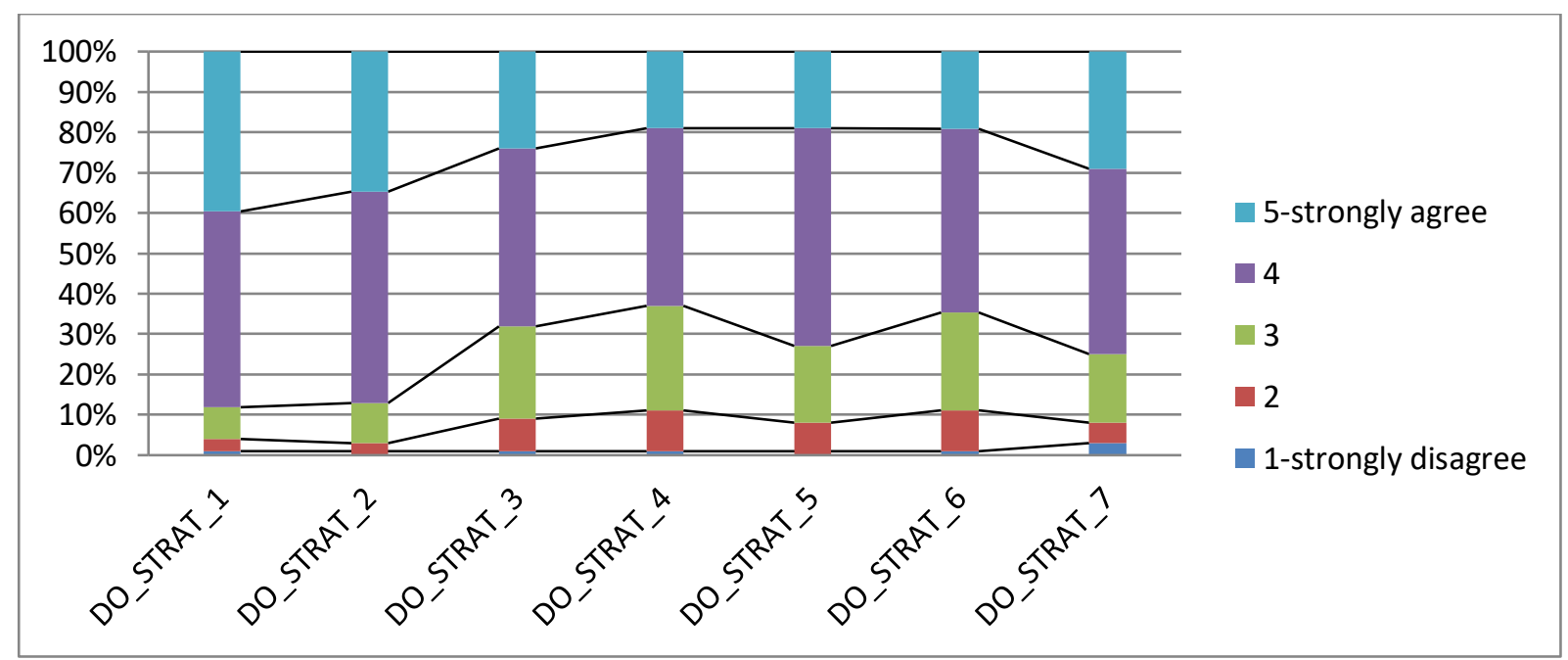

Source: Authors' illustration

Figure 2 represents a graphic display of the structure of examinee answers for representation of the corporate social responsibility construct within the strategy of a company. Greatest number of examinees awarded all lots a four or a five, which proves they agree with the aforementioned statements, most of all the following two: DO_STRAT_1 (Corporate social responsibility incorporated within company strategy 
as one of the key strategy elements) and DO_STRAT_2 (Corporate social responsibility represented in the company mission which is the key element of company strategy).

\section{Conclusion}

Even though the concept of corporate social responsibility has had a very dynamic past, its future will be even more important for the global community and its existence (Carroll, 2015). Today corporate social responsibility is considered an important strategy element of profit, but also non-profit organizations which constantly become more powerful because of the development of informationcommunication technologies (Omazić, 2006). Sustainable competitive advantage and consequently a positive business result are the outcome of a quality corporate strategy with incorporated parts of a socially responsible strategy, adhered to by all organizational levels within a company (Tipurić, 2014). Unconnected initiatives out of sync with strategic goals can create a financial burden and unplanned costs, which may endanger potential gains by differentiation through the concept of corporate social responsibility and a better perception by the stakeholders (Tang et al., 2012).

On the other hand, companies that completely ignore societal and ecological aspects of their business operations within the global network can be successful in the short term, but endanger their business and existence on the global as well as national markets in the long term (Jamali et al., 2018). A planned approach by the management can confirm in practice what is proven in scientific theory, namely, a direct positive connection between corporate social responsibility and the company's financial results (Rangan et al., 2012). Periodic conducting and uncoordinated communicating of socially responsible activities can create a counter-effect because certain stakeholders can see these activities as tools for selfpromotion, and without real value added in practice (Rosińska-Bukowska et al., 2015). Besides, in the short term, sporadic initiatives which generate cost without economic benefits can have a very negative effect on the management which can consequently completely give up on the concept of corporate social responsibility in business out of fear (Tang et al., 2012).

Based on the aforementioned, particularly because of the survival and advancement of a community we live in, it is important that maximum efforts are made within the scientific and business communities in order for the concept of corporate social responsibility, as well as its connection to corporate strategy, to remain a successful subject of research and presentation to stakeholders.

\section{References}

1. Bluementhal, D., Bergstorm, A. J. (2003), "Brand councils that care: Towards the convergence of branding and corporate responsibility", Journal of Brand Management, Vol. 10, No. 4-5, pp. 327-341.

2. Boehe, D. M., Cruz, L. B. (2010), "Corporate social responsibility, product differentiation strategy and export performance", Journal of Business Ethics, Vol. 91, No. 2, pp. 325346.

3. Bogdan, Ž., Cota, B., Rogić, L. (2015), "Modeliranje funkcije robnog izvoza Republike Hrvatske u uvjetima recesije" (Modeling the function of export of the Republic of Croatia in the conditions of the recession), Ekonomski pregled, Vol. 66, No. 4, pp. $321-$ 357.

4. Carroll, A. B. (2015), "Corporate social responsibility", Organizational dynamics, Vol. 44, No. 2, pp. 87-96.

5. Galbreath, J. (2009), "Building corporate social responsibility into strategy", European Business Review, Vol. 21, No. 2, pp. 109-127.

6. Googins, B., Rochlin, S. (2006), "Corporate citizenship top to bottom: vision, strategy, 
and execution", The Accountable Corporation, Vol. 3, No. 1, pp. 111-129.

7. ISO (2010), "Guidance on social responsibility, international standard, ISO/FDIS 26000", ISO copyright office, Geneva.

8. Jamali, D., Karam, C. (2018), "Corporate social responsibility in developing countries as an emerging field of study", International Journal of Management Reviews, Vol. 20, No. 1, pp. 32-61.

9. Kanji, G. K., Chopra, P. K. (2010), "Corporate social responsibility in a global economy", Total Quality Management \& Business Excellence, Vol. 21, No.2, pp. 119-143.

10. Lamberti, L., Lettieri, M. (2009), "CSR practices and corporate strategy: evidence from a longitudinal case study", Journal of Business Ethics, Vol. 87, No. 2, pp. 153-168.

11. Lins, K. V., Servaes, H., Tamayo, A. (2017), "Social capital, trust, and firm performance: The value of corporate social responsibility during the financial crisis", The Journal of Finance, Vol. 72, No. 4, pp. 1785-1824.

12. Manolova, T. S., Manev, I. M., Gyoshev, B. S. (2010), "In good company: The role of personal and inter-firm networks for new-venture internationalization in a transition economy", Journal of World Business, Vol. 45, No. 3, pp. 257-265.

13. Maon, F., Lindgreen, A., Swaen, V. (2010), "Organizational stages and cultural phases: A critical review and a consolidative model of corporate social responsibility development", International Journal of Management Reviews, Vol. 12, No. 1, pp. 2038.

14. Marcus, A. A., Anderson, M. H. (2006), "A general dynamic capability: does it propagate business and social competencies in the retail food industry?", Journal of Management Studies, Vol. 43, No. 1,pp. 19-46.

15. Omazić, M. A. (2006), "Društvena odgovornost i strategije hrvatskih poduzeća" (Corporate Responsibility and Strategy of Croatian Enterprises), Doctoral disertation, Faculty of Economics and Business, Zagreb.

16. Rangan, K., Chase, L. A., Karim, S. (2012), Why every company needs a CSR strategy and how to build it, Harvard Business School, Boston.

17. Rosińska-Bukowska, M., Penc-Pietrzak, I. (2015), "Corporate social responsibility in corporate strategy in the globalised economy", Administracja i Zarzadzanie, Vol. 33, No. 106, pp. 195-208.

18. Scherer, A. G., Palazzo, G. (2008), "Globalization and corporate social responsibility", in Crane, A., McWilliams, A., Matten, D., Moon, J., Siegel, D. (Eds.), The Oxford handbook of corporate social responsibility, Oxford University Press, New York, pp. 413431.

19. Tai, F. M., Chuang, S. H. (2014), "Corporate social responsibility", Ibusiness, Vol. 6, No. 3 , p. 117.

20. Taneja, S. S. Taneja, P. K. Gupta, R. K. (2011), "Researches in Corporate Social Responsibility: A Review of Shifting Focus, Paradigms, and Methodologies", Journal of Business Ethics, Vol. 101, No. 3, pp. 343-364.

21. Tang, Z., Hull, C. E., Rothenberg, S. (2012), "How corporate social responsibility engagement strategy moderates the CSR-financial performance relationship", Journal of Management Studies, Vol. 49, No. 7, pp. 1274-1303.

22. Tata, J., Prasad, S. (2015), "CSR communication: An impression management perspective", Journal of business ethics, Vol. 132, No. 4, pp. 765-778.

23. Tipurić, D. (2014), Iluzija strategije - Razotkrivanje socijalno konstruirane zbilje poduzeća (Illusion of the Strategy - Disclosure of a Socially Constructed Business Reality), Sinergija nakladništvo, Zagreb.

24. Tsoutsoura, M. (2004), "Corporate Social Responsibility and Financial Performance", Haas School of Business, University of California at Berkeley. 


\section{About the authors}

Andrija Baric graduated from the Faculty of Economics and Business in Zagreb, Republic of Croatia, with master degree in finance. He received Ph.D. in Management at the same university with the dissertation thesis „Relationship between corporate social responsibility and export activities of medium-sized and large Croatian companies". Currently, he works in KONČAR - Power Plant and Electric Traction Engineering Inc. as CFO. His main research is corporate social responsibility in export process. The author can be contacted at andrija.baric@koncar-ket.hr.

Mislav Ante Omazić started to work at the Faculty of Economics and Business Zagreb as a Teaching Assistant at the department of Organization and Management. Today he is Associate Professor of the same institution where he teaches a variety of classes such as Corporate Social Responsibility, Business Ethics, Management, Project Management and Change Management. He worked on various domestic and international projects for public, private and civil society organizations. During his research work, professor Omazić has published dozens of papers in professional and scientific journals home and abroad and is the author and editor of several books. Above everything he is a proud father of two young boys. The author can be contacted at momazic@efzg.hr. 